\title{
Standpoint Theory in Professional Development:Examining Former Refugee Education in Canada
}

Vanessa Braun

University of Regina

\begin{abstract}
On September 2, 2015, a toddler was photographed on an unnamed Turkish beach in a position reminiscent of a baby sleeping in his crib. Alan Kurdi would instantly become the poster child for an entire nation that had no other alternative but to run and risk their lives on inflatable dinghies. On the open expanse of the Mediterranean Sea, the rate of survival was much higher than staying in Syria. On December 11, 2015, the newly elected Canadian Liberal majority government opened up Canada's borders to Syrian refugees, and the Canadian education system is now grappling with how to adequately address the needs of their former refugee students. This article examines how deficit discourse affects academic excellence of all English as an Additional Language (EAL) learners, including former refugee students, and how professional development offers a cost-effective solution to the effects of deficit discourse on former refugee students, while equipping teachers with reliable skills and tools to use in diverse classrooms. In addition, this article investigates how standpoint theory can be used as the foundation for professional development programming for teachers of all students, including those who were refugees.
\end{abstract}

Keywords: education; deficit discourse; standpoint theory; refugee

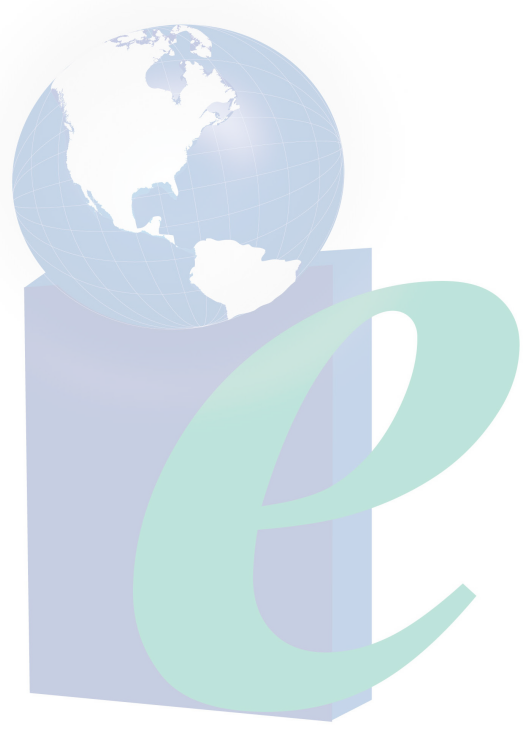




\section{Standpoint Theory in Professional Development: Examining Former Refugee Education in Canada}

As the number of Syrian refugees welcomed into Canada continues to increase, concern for the education of refugee children has made its way into the media across the nation. Numerous newspaper articles calling for increased government funding, more hiring of English as an Additional Language (EAL) specialists, and better programming to aid teachers, students, and administrators are published almost daily (e.g., Bissett, 2016; Bonnell, 2015; "Regina Teachers Group,” 2016; "School Boards,” 2016; Tutton, 2016). In particular, numerous teacher groups in Saskatchewan have lobbied Brad Wall and the Saskatchewan Party for further hiring capabilities (“Regina Teachers Group,” 2016). In response to the rapid change in my teaching context, I wish to challenge the argument that more money circulating through the education system is the only way to diminish the tensions created by Canada's response to the Syrian refugee crisis. While the hiring of additional personnel in school systems is a legitimate response to the concerns for refugee children in Canada, as a teacher in Saskatchewan, I believe that it is only part of a more crucial response to deficit discourses embedded in our education system. Instead, I propose that professional development rooted in standpoint theory offers a viable and permanent solution to addressing such discourses.

Before turning to how the Syrian refugee crisis garnered international attention and how Canada has chosen to respond, I would like to clarify my use of the term refugee in this article. According to the 1951 United Nations Refugee Convention, a refugee is defined as someone who has a "well-founded fear of being persecuted... is outside the country of his nationality, and is unable to... avail himself of the protection of that country" (UN General Assembly, 1951, p. 152). Following a study by Shapiro (2014), I will use the term former refugee to address Syrians who now live in Canada because "the label 'refugee' does not fully capture who students are in the present” (p. 392). I would also like to acknowledge the power I have in my positioning as a teacher and the privilege I have as a Canadian teacher. By recognizing that Syrian children who have entered Canada via refugee status are now former refugees, I hope to bring to attention the current value of former refugees in Canada, which includes both past and present identities.

Drawing on North American literature on former refugee students in schools and professional development of teachers in EAL learning, I offer commentary on how the province of Saskatchewan could be leveraging professional development to equip current teachers with alternate frameworks and tools to encourage the academic success of former refugee children. I begin by investigating how the duties of the federal and provincial governments create a gap in resources for former refugees in Canada. Then, I examine how deficit discourses pervade the Canadian education system, how English as an Additional Language (EAL) programming offers a glimpse into how every classroom should look, and how professional development is the critical step towards best practice. Finally, I discuss standpoint theory, which is the body of work that identifies social location as the key to individual subjectivity and that posits that the perspectives of minority groups can create objective accounts of the world ( $\mathrm{Au}, 2012)$, which can promote a necessary perspective shift away from deficit discourses in schools across Canada. First, however, I review how the Syrian refugee crisis began and how it is impacting Canadian schools. 


\section{How a Refugee Crisis Came to Canada}

It took the tiny, frail body of three-year-old Alan Kurdi to wash up on a Turkish beach for the West to take notice of a mass exodus of refugees that was over four years in the making (Blizzard, 2015). It was March of 2011 when violent uprisings in Syria began against President Bashar al-Assad who, in his claim for power, severely punished all those who defied him. By the end of 2011, civil war had broken out between supporters and rebels intent on breaking President Assad's reign. Since then, the United Nations (UN) has investigated both groups for war crimes, including for the use of chemical warfare. Millions of people fled their warring nation in the hopes of finding refuge in the international community. In June 2014, the Islamic State declared a caliphate in Syrian and Iraqi territories, after taking advantage of years of turmoil in Syria, which resulted in a US-led coalition in September. The coalition was designed to both breakdown Islamic State, as well as dismantle the Assad regime. Many argue that the coalition has not done what it was set out to do; instead, it has only forced Syrian civilians into a further state of despair ("Syria: The Story of Conflict," 2016). Since 2011, 4.5 million people have fled Syria. Many have ended up in refugee camps in neighbouring nations, such as Lebanon and Jordan. Others have attempted to leave the area entirely: paying what they can to have smugglers take them in small, overcrowded, inflatable rafts, across the Mediterranean Sea in the hopes of finding safety and security in Europe. In 2015, over one million refugees attempted to cross the Mediterranean Sea, compared to 280,000 in 2014 ("Why is EU Struggling With Migrants and Asylum,” 2016). Many died on their journey across the sea, including three-year-old Alan Kurdi, who became the poster child for the refugee crisis.

Although it took years for Canadians to notice the crisis, it took only moments after Alan's lifeless body was photographed on a Turkish beach for Canadians to begin responding through social media (Ayed, 2015). September 2, 2015 saw the shift towards humanitarian aid for every "Alan Kurdi” fleeing the conflict in Syria. Stories were shared thousands of times on social media. Canadian federal political parties, already campaigning for an election in the fall of 2015, began including promises of aid for Syrian refugees in their campaigns ("Canada and the refugee crisis,” 2015). In November 2015, the Liberal Party won a majority government and kept its promise to settle 25,000 Syrian refugees in Canada by March 2016 ("25,000th Syrian Refugee,” 2016). Since the resettlement, news coverage has begun to shift from questions about the acquisition of basic human necessities for Syrian refugees (Huber, 2015) to the education of former refugee children ("Regina Teachers Group," 2016). For instance, the Regina Public School Teachers' Association (RPSTA, 2016) in Regina, Saskatchewan, has spoken up about the complex needs of 128 former refugee students in their school division and the lack of additional resources provided. These resources include hiring more educational psychologists, and English as an Additional Language (EAL) teachers, as well as educational assistants for teachers (RPSTA, 2016).

\section{Professional Development}

With the focus on funding and hiring of new staff, however, little is being done to address how current teachers are handling the needs of former refugee children, whether or not they are prepared, and how professional development could help teachers provide the best for former refugee families in their schools and community. Professional development refers to the professional growth of a teacher, accomplished through both individual and group reflection, the examination of current trends in education, and one's ongoing analysis of core beliefs and values 
within education (Richards \& Farrell, 2005). Professional development can be done both formally and informally in venues such as teacher conferences and professional learning networks (PLN). The idea that professional development is not being taken seriously by school divisions and the government is evident, particularly in the lack of professional development offerings relating the Syrian refugee crisis to professional development.

Why the relationship between professional development and the Syrian refugee crisis is not immediately clear is two-fold: It is not a quick fix solution and it is not simply measurable. For instance, if teachers, as part of professional development programming, are expected to examine and critique their own beliefs and practices in the classroom, especially in regards to their own deficit discourse, time cannot be constricted. Furthermore, unlike other areas of professional development that result in tangible, standardized, and measurable results (e.g. higher test scores in children), professional development related to beliefs and values may not result in such effects because the core principles of said development are not grounded solely in content acquisition, but in the holistic development of all children in the classroom. In this case, professional development is seen as an ongoing experience, one that extends beyond practice and into teachers' foundations. For Canadian society, money is scarce, but time is scarcer and cannot be handed out by the government. Therefore, administrators lobby for what they can receive from the government and what will evoke the most positive response from the public.

\section{A Disconnect Between Provincial and Federal Government Funding}

Unfortunately, funding for any additional hiring or professional development programming is not available to schools from the federal or provincial governments. Citizenship and Immigration Canada is the federal office responsible for receiving and processing immigration applications, including refugee applications. With a large number of refugees entering Canada on governmentassisted plans, the government has put millions of dollars towards resettlement assistance programs to help them adjust to Canadian life ("Financial Assistance,” 2016). This includes immediate attention to food, clothing, and shelter as well as a stipend for the first year (“Government-assisted refugee,” 2014). Beyond the support for basic needs, the government program addresses education as a mandatory part of the Canadian experience, but because education is a provincial mandate, the federal government does not offer specifics with respect to the reception of former refugee students into Canadian schools. The probable cause of this is that although the basic resettlement plan for former refugees is through the federal government, most other offices that they will need in order to become settled are provincial. This is evident in the section "finding a job" of the government brochure: "It will be up to the provincial government... to determine whether or not your degree/certificate or other credentials are recognized” (“Government-Assisted Refugee,” 2014, p. 6). The federal government leaves most additional needs, including education, to the provincial government.

In Saskatchewan, as in other Canadian provinces, the Ministry of Education is the provincial body that regulates education. It offers numerous EAL programs to address the specific needs of school-aged children who are new to Saskatchewan and who are learning English as an additional language, including former refugees ("English as an Additional Language,” 2012). Beyond providing a toolkit for EAL support and funding for EAL programs, however, the provincial government leaves the development and implementation of the programs up to individual school divisions. Due to the evident separation of responsibilities for former refugee students in the Canadian public education system, teachers are largely left with the 
responsibility of integrating former refugee students into Canadian society. Additionally, there are no targets set by the provincial government, such as curricular outcomes, specific for former refugee children who have had very different experiences than other English language learners from immigrant backgrounds. In fact, the Saskatchewan Ministry of Education simply requires that all EAL learners "follow the provincial curriculum, and educators should guard against watered down versions of subject areas” (Saskatchewan Rivers Public School Division, n.d.). The obvious reason for this policy is to combat deficit discourses about former refugee children in school.

\section{Deficit Discourse in Education}

In this paper, I would like to discuss what I see as three main sources of deficit discourse about former refugee students and the school environment: policy, those who implement policy, and self-fulfilling prophecy. Deficit discourse, related to education, is how the social and economic standing of an individual or group different from the dominant hegemony predetermines their status in the education system. First, policy is often a carrier of deficit discourse. This is significant because policy serves as a link between policy makers and stakeholders and those whose work is shaped by policies (e.g., teachers and school administrators). Shapiro (2014) detailed the personal narratives of former refugee students in a northern New England town where the majority of former refugees came from Central and Eastern Africa, the Middle East, and Asia. He discovered that deficit discourses have invaded many aspects of former refugee students' education. For example, after a series of standardized tests were given to place all students into high school programs, the results were published in a local newspaper where people of African descent were grossly overgeneralized and marked as the reason for low test scores in the school, even though the former refugee population was not solely students from Africa (Shapiro, 2014). The students argued that the standardized tests "did not measure their actual abilities, and therefore put them on an academic track that was below their capabilities" (Shapiro, 2014, p. 395). This example points to the effects of government-instituted policies such as standardized testing, demonstrating that "standardized tests are a... method of racial profiling in schools,” in situations where refugees have been racialized (Malsbary, 2015, para. 9).

In Saskatchewan, standardized testing is a common form of assessment, although it is not used to stream students. Instead, it provides quantitative data for teachers, students, parents, and administration on trends of learning ("Raising the Bar," 2016). However, these data are based on standards designed by a corporation that reflects the dominant culture. In 2011, Pearson was granted the contract to develop the framework for the 2015 PISA assessment (Campbell, 2014). Pearson is a multi-billion dollar corporation and the head of PISA testing sits on their board. PISA is a highly respected international test, for better or for worse, and as such, provides the hegemony with even more power. What are the results when these assessments are given to students who are still learning English and/or may be unfamiliar with the culture of the examination? If standardized tests are as the students in Shapiro's (2014) research argued, then the actual abilities of former refugee students are not being properly assessed.

In addition to policy, people who implement and interpret the written curriculum can inadvertently exacerbate deficit discourses. For instance, in the Saskatchewan curriculum, Social Studies outcome IN5.2 states, "Analyze the evolution of Canada as a multicultural nation” (Saskatchewan Ministry of Education, 2010, p. 19). Former refugee children who have been subjected to racism and religious persecution may respond differently to the idea of a 
multicultural society, such as the one included in the Saskatchewan curriculum, than Canadianborn students. What is important is how the teacher responds to such an outcome and whether or not he/she addresses the critiques of multiculturalism alongside the praise. In addition, the mathematics outcome SS4.4, "Demonstrate an understanding of line symmetry" (Saskatchewan Ministry of Education, 2007, p. 28) may not relate to a student whose understanding of mathematics has been traditional, rote, and hierarchical in terms of abstract and concrete numeric material. In Canada, the most common method to "demonstrate an understanding" is taking an exam, yet refugee children often have interrupted education plans that impact test-taking abilities, or lack the necessary language skills to read the mathematics exam. Instead, teachers should be encouraged to utilize alternate ways of assessment such as shorter exams, verbal exams, portfolios, or unit projects. These methods give students the opportunity to depend less on their writing skills and more on their learning process. Teachers are rarely encouraged to examine their own deficit understandings and, without the skills to properly assess deficit discourse, the result can be discrimination. Pedagogical tools used to teach the curriculum are also valuable professional development, but teachers need to begin examining their discourse because words are a starting point for deficit thinking.

Linked closely to racism and other forms of discrimination, the above examples highlight the effects of deficit thinking in the education of former refugee students. However, deficit thinking is not only evident in the dominant group; it can also create a self-fulfilling prophecy for former refugee students, one where students inadvertently cause a prediction to come true because they believe it will come true. A study by Roxas (2012) examined the story of the selffulfilling prophecy through Abdullah, a male Somali Bantu former refugee student in the United States. He is described as being a model student in his first year of high school, but by the time he entered his third year, he was at risk of failing (Roxas, 2012). Deficit thinking by his peers and teachers led to absenteeism, incomplete work, and physical aggression. Similar situations are visible in a number of other case studies documenting not only former refugee students' transitions into North American schools, but also English Language Learners (ELL) students and any persons who are not a part of the dominant hegemony (Agirdag, Van Avermaet, Van Houtte, 2013; Montgomery, 2013; Van Den Bergh, Denessen, Hornstra, Voeten, \& Holland, 2010).

Although the self-fulfilling prophecy when paired with deficit discourse often results in decreased achievement of former refugee students, it is important to recognize that the selffulfilling prophecy is inherently neutral; that is, if coupled with equity, the results can be overwhelmingly positive. A look at Sierra Leone refugees in the American school system substantiates this claim (Davies, 2008). From the examination of five former refugee students, one American teacher commented on how students rose to the challenge of having high expectations placed on them by their teachers. Furthermore, all students saw that the school environment was the most important aspect of their adaptation into American schools and, in their comments, associated school to "family." Through a caring and trusting school environment, former refugee students are able to use self-fulfilling prophecies to their advantage and ultimate success.

Policy, teacher perspectives, and the self-fulfilling prophecy are barriers for former refugee students when associated with deficit discourse. Because deficit discourse related to former refugee students is so pervasive in North American schools, addressing it is critical. In Canada, however, particular attention has been paid to funding additional language resources for teachers, as opposed to addressing deficit discourse. It is undeniable that learning English in 
Canada, as well as French in Quebec and New Brunswick, is a crucial step for former refugee students to integrate into Canada. In accordance with the supporting literature, a Saskatchewan teaching association representing Regina public school teachers, has asked the public school division for financial help, but has been turned away because of the lack of funding from the province ("Regina Teachers Group," 2016). In addition, both the province and Saskatchewan School Boards Association (SSBA) are lobbying for more federal funding to aid EAL programs across Saskatchewan (“School Boards,” 2016). The money, if acquired, would be spent on hiring support staff for teachers, EAL instructors, and resources for students.

\section{Language Development as Critical but not Exclusive}

Other provinces across Canada are also struggling with the growing numbers of former refugee students in their classrooms. New Brunswick, recognizes that “while more funding hasn't been confirmed from the government... [money] isn't an immediate solution either” (Bonnell, 2015, para. 9), and is seeking support of private businesses for the education of former refugees in English and French. Nova Scotia and British Columbia are citing unpreparedness of their schools as a major deterrent to the successful integration of former refugee children into Canadian schools (Laroche, 2016; Rolfsen, 2016). The focus for all of these provinces is similar to Saskatchewan: that is, hire more professionals who can encourage the English development and support the psychological well-being of students, many of whom work individually with students or in small groups (Bonnell, 2015; Laroche 2016; Rolfsen, 2016). Few would dispute that learning the dominant language of a culture is the first step for former refugee children to become part of a school and eventually a society. In this sense, it is appropriate for teaching associations and governments to ask for additional funds for hiring more staff.

However, by using private businesses for language development and additional EAL support teachers for pull-out programs-programs where EAL students are removed from the classroom to learn both English and Canadian norms-provinces run the risk of creating normative social categories, where students become their deficiency, English learners, while their other social identities are ignored and even suppressed (Gonzalez et al., 1992). Even the term "EAL learners" promotes deficit discourse by promoting the idea that students who are native-English speakers are not learning English and thus those who are learning it additionally are less valued by mainstream education (Crumpler, Hansfield, \& Dean, 2011). Moreover, Bauman (2004) asserts that former refugee students "are stripped of every single element of their identities except one: that of stateless, placeless, functionless, refugees” (p. 15). This vulnerability, along with disruption of education and trauma, puts them at even higher risk of being inappropriately categorized (Sirin \& Rogers-Sirin, 2015). Therefore, especially for former refugee children, it is not only important to address English acquisition as a skill; but it is also important to address how English should be taught, under what circumstances, and what other factors contribute to success in a new country.

\section{Inclusion at the Heart of EAL Education}

According to Rutter (2006), there are three critical points to good practice in EAL education: the fulfillment of linguistic and psycho-social needs, the importance of a hospitable classroom, and a welcoming school environment, free from discrimination. For former refugee educational achievement, an inclusive learning community is pertinent, one where students are able to experience a welcoming environment (Davies, 2008). Arnot and Pinson (2010) identifies a 
holistic model of inclusion as one where the focus "derives from a humanitarian and humanistic concern for the child... and the principle of social inclusion through the recognition of difference" (p. 255). Currently, EAL programs in Saskatchewan are inclusive in theory. There are a few online documents related to how teachers can communicate inclusivity in the classroom. A number of practical guidelines relate to how teachers can make students feel welcome in a Saskatchewan classroom with other students, such as "partner EAL students with a classroom ambassador (possibly someone who speaks the same language)" and "encourage continued use of the first language while students are acquiring English” (Sterzuk \& Vandall, n.d.). These recommendations offer hands-on methods of how teachers can begin forging trusting relationships with and between their students in their language of origin; yet, in their practicality, they may force teachers into a false sense of security by not addressing deficit discourse at its root. Rather, hands-on methods may actually mask deficit discourses evident in other aspects of teaching by deterring teachers from addressing the theory behind the practice. On the other hand, professional development programming (e.g. professional learning groups), offers individualized action plans designed by educators for teachers involved in EAL programs for former refugee students because of the mutual complexity of both problem and solution.

Professional development provides the opportunity for the development of good practice in inclusive education, even though it is often disregarded and underfunded in the Canadian education system. Ironically, however, Karabenick and Noda (2014) noted that professional development is not only a viable solution in terms of effectiveness in encouraging both good practice with and efficacy towards teaching EAL learners, but also in terms of cost, as the difference between hiring additional support and training teachers is substantial. This is not to say that hiring additional support is not important, but rather that it is only one piece of the solution. Nonetheless, beyond British Columbia's professional development day in February for preparing teachers to teach former refugee children (Rolfsen, 2016), there has been little discussion about funding job-embedded professional development for teachers who have former refugee students in their classes, nor discussions on how professional development could help overwhelmed teachers in the areas of EAL teaching and former refugee student education.

\section{Professional Development as a Tool}

In Saskatchewan, a number of professional development opportunities are available. Those that relate to EAL teaching and/or teaching former refugee students include areas such as "social justice and equity... safe and caring schools... [and] responding to diversity: differentiated instruction” (“Contracted Services,” n.d.). However, these opportunities are more often than not optional. Cummins and Persad (2014) argue, "Most classroom teachers... have had no... professional development preparation focused on appropriate instruction for EAL/multilingual students [in Canada]" (p. 4). There are two main reasons that classroom teachers may not be engaging in professional development. First, they may not be pursuing it because they do not have enough information about the training. If so, the solution is simple: teachers must be provided with enough information from their administration so they can make informed decisions about the types of professional development available to them. Second, teachers may not see value in the professional development programming being offered. If this is true, there is a more complex solution: teachers must be invited to see how professional development works and how it can foster a better understanding of teaching former refugee children. 
Although the literature on professional development for teachers of former refugee students is limited, a number of recent studies (Karabenick \& Noda, 2004; Tran, 2014) support the notion that professional development experiences related to EAL learners are overwhelmingly positive for both teachers, as skill developers, and students, as beneficiaries. Because former refugee students are often EAL learners, this body of literature is relevant to this article. Tran (2014) studied the effects of professional development on teaching EAL learners and found that long-term pedagogical change resulted from participation in professional development. Following a large quantitative survey, the researcher closely documented the professional development programming of five of the participants. The PD was independent of the researchers and not administered by the researchers. The participants engaged in selfreflection and self-reported ratings of their perceptions about pedagogy and instruction. Tran found that these teachers showed a shift in their pedagogy, which included an inclination to use differentiated instruction and to use real-world scenarios during instruction. Furthermore, through professional development, teachers can develop an increased perception of efficacyone's belief in one's ability to succeed-when teaching EAL learners, which impacts teachers' tendency to use differentiated instruction (Dixon, Yssel, McConnell, \& Hardin, 2014). For example:

Teachers who employ differentiated instruction adjust their teaching for students of differing abilities in the same class with the intent of maximizing each student's growth and individual success by meeting each student where he or she is and assisting in the learning process. (Dixon, Yssel, McConnell, \& Hardin, 2014, p. 113)

Teachers who have higher self-efficacy recognize the importance of differentiated instruction to encourage their students to learn. Karabenick and Noda (2014) recognized that teacher efficacy was not independent of teachers' beliefs and perceptions of EAL learners; rather, teachers who have a positive attitude toward EAL learners were more likely to foster higher levels of selfefficacy than the teachers who had a negative attitude.

In order for teachers to develop greater efficacy and as a result, student efficacy and achievement, they must take aa deeper look into their beliefs and values. Professional development has the potential to help teachers deconstruct "their own cultural and intellectual situatedness in the curriculum and pedagogy of formal schooling” (Kanu, 2008). In the westernized world, education is based in legislation. Students in both Canada and the United States must attend school and follow a provincial or state curriculum until they turn 16 . Because of this, Canadian and American societies put immense emphasis on formal schooling and hold it above all other forms of education. In order for Canadian teachers to work towards a healthier relationship with EAL learners, specifically former refugee students who often have interrupted schooling, an important first step is questioning the hierarchy of schooling. Standpoint theory, as I explain in the next section, offers one tool for this.

\section{Executing Professional Development Through Standpoint Theory}

Through professional development, educators and administrators have the opportunity to learn new skills, which can result in both pedagogical and intrinsic change. However, professional development also has limitations. The most obvious, yet most profound, is that professional development cannot alter the past experiences of teachers related to political and/or social location. Fleischman and Hopstock (1993) recalled that teachers and students who have similar 
cultural or socio-economical backgrounds are more likely to interact frequently. In the same way that former refugee students cannot change their past experiences or their inherited nationality, neither can teachers exist in a social location beyond their own. However, standpoint theory offers an alternative to the impossible task of voluntarily moving into alternate social locations, particularly for educators who are passionate about providing the equal education for all students.

Standpoint theory, according to Harding (1992), values "the lives of marginalized peoples... as the 'starting off thought'... [that] will generate illuminating critical questions that do not arise in thought that begins from dominant group lives” (p. 445). Furthermore, standpoint theory "argues that we can achieve more objective understandings... by embracing our subjectivity consciously and actively reflecting on it within our socio-political environments" (Au, 2012, p. 57). Standpoint theory developed out of feminism as a way to address bodies of knowledge that are inherently patriarchal. Dorothy Smith (1989) addressed the objectification of women in sociology and how women's roles in society had been seen as instinctual and natural, rather than grounded in culture. Although standpoint theory was developed as a response to misogyny in academia, its applications in all areas of education are not lost. Currently, the directives in place for former refugee students in Canada have not developed out of the social locations of the marginalized group; rather, they have been created from the same dominant discourse that has been operating well before the Syrian refugee crisis. If educators apply standpoint theory before addressing the circumstances by which former refugee children enter the Canadian education system, they will be better equipped to help displaced children transition into their new learning environment and support their success. Additionally, if professional development is built on a foundation of standpoint theory, then the best interests of former refugee students will be authentically embedded in the pedagogical stances and skills developed.

Two pedagogical stances that emerge from standpoint theory are curricular standpoint and troubling knowledge. In order for former refugee students to be successful, the entire embodiment of the curriculum must "relate to students' contexts, experiences, identities, and material realities" (Au, 2012, p. 67). Additionally, the curriculum must "work paradoxically with knowledge" as well as present "knowledge that is disruptive, discomforting, and problematizing" (Kumashiro, 2004, pp. 8-9). In regards to the Saskatchewan Social Studies outcome IN5.2: "Analyze the evolution of Canada as a multicultural nation” (Saskatchewan Curriculum Social Studies 5, 2010, p. 19), encouraging students to ask whether or not Canada is multicultural and how this affects perceptions of Canada is one concrete way to develop curricular standpoint in the classroom. The indicator "differentiate between immigrants and refugees" (Saskatchewan Curriculum Social Studies 5, 2010, p.19) is part of the outcome IN5.2. Challenging the conventional image of the refugee is one way to bring troubling knowledge into the fifth grade classroom, for example. Even today, "the fact... that refugees had property, education, and status before they were driven from their homes by forces beyond their control is less emphasized than their present impoverished circumstances” (Kaprielian-Churchill \& Churchill, 1994, p. 117).

It should be recognized that though standpoint theory addresses issues from the perspective of the minority, the minority is not the only beneficiary of these pedagogical frameworks. Standpoint theory is a theory for justice and it is also inherently inclusive; the only way to attain knowledge that is more objective and true in a standpoint framework is by listening and trying to understand the perspectives of those around us. Standpoint theory is as much about equitable resources and opportunities for all people, as it is about recognizing the societal power 
of social location. Through standpoint theory, teachers and educators can begin to focus on curricular and pedagogical inequality in the classroom, which not only aids in addressing hegemony in the classroom, but could also lead to changes in policy, such as standardized testing.

Professional development grounded in standpoint theory is a cost effective method to encourage educators to authentically produce equitable opportunities for all students in their classrooms, but particularly former refugee students, providing them with tools and strategies they need to encourage academic achievement. If used in partnership with hiring additional support in the form of EAL teachers, educational assistants, psychologists, and counsellors, educational equity could extend far beyond the classroom. More research needs to be done on how standpoint theory and professional development interact, and whether or not mandatory professional development is a solution to closing the achievement gap between Canadian-born and former refugee students (Levels, Dronkers, \& Kraaykamp, 2008).

Professional development grounded in standpoint theory is one possible long-term goal for helping teachers be prepared to support the success of all their students. Although allocating the majority of funds for hiring new staff is an important immediate action by the government and school districts, it should not be the only option considered. As Canadian teachers grapple with dramatic shifts in their classrooms and former refugee students fight against the loss of their identities, it is essential to consider broader ways of addressing what actions can be taken to immediately support both parties. 


\section{References}

25,000th Syrian refugee lands in Canada. (2016, February 27). CBC News. Retrieved from http://www.cbc.ca/news/canada/montreal/25-000th-syrian-refugee-lands-in-canada$\underline{1.3467886}$

Agirdag, O., Van Avermaet, P., \& Van Houtte, M. (2013). School segregation and math achievement: A mixed-method study on the role of self-fulfilling prophecies. Teachers College Record, 115(3), 1-50.

$\mathrm{Au}, \mathrm{W}$. (2012). Critical curriculum studies: Education, consciousness, and the politics of knowing. New York, NY: Routledge.

Ayed, N. (2015, September 03). Little Alan Kurdi, washed ashore, suddenly refocuses Syrian tragedy. CBC News. Retrieved from http://www.cbc.ca/news/world/little-alan-kurdiwashed-ashore-suddenly-refocuses-syrian-tragedy-nahlah-ayed-1.3213893

Bauman, Z. (2004). Wasted lives: Modernity and its outcasts. Cambridge, UK: Polity Press.

Bissett, K. (2016, July 8). Influx of Syrian refugees overwhelmed N.B. school. The Canadian Press. Retrieved from http://globalnews.ca/news/2811724/sudden-influx-of-syrianrefugees-overwhelmed-n-b-high-school-documents/

Blizzard, C. (2015, September 3). Canada must ensure little Alan Kurdi did not die in vain. Toronto Sun. Retrieved from http://www.torontosun.com

Bonnell, I. (2015, November 27). Language teachers preparing for influx of Syrian refugees. CBC News. Retrieved from http://www.cbc.ca/news/canada/new-brunswick/languageteachers-syrian-refugees-1.3339485

Campbell, A., (2014, December 3). Pearson testing comes to Canadian classrooms [Web log post]. Retrieved from http://www.easybib.com/guides/citation-guides/apa-format/how-tocite-a-blog-apa/

Canada and the refugee crisis: Four things to know before you vote. (2015, October 16). The Globe and Mail. Retrieved from http://www.theglobeandmail.com/news/politics/canadaand-the-refugee-crisis-four-things-to-know-before-youvote/article26363975/

Contracted services. (n.d.). Retrieved from https://www.stf.sk.ca/professionalresources/saskatchewan-professional-development-unit/contracted-services

Crumpler, T. P., Hansfield, L. J., \& Dean, T. R. (2011). Constructing difference differently in language and literacy professional development. Research in the Teaching of English, 46(1), 55-91.

Cummins, J., \& Persad, R., (2014). Teaching through a multilingual lens: The evolution of EAL policy and practice in Canada. Education Matters, 2(1), 1-38.

Davies, A. Z. (2008). Characteristics of adolescent Sierra Leonean refugees in public schools in New York City. Education and Urban Society, 40(3), 361-376. 
Dixon, F. A., Yssel, N., McConnell, J. M., \& Hardin, T. (2014). Differentiated instruction, professional development, and teacher efficacy. Journal for the Education of the Gifted, 37(2), 111-127.

English as an additional language. (2012). Retrieved from https://www.saskatchewan.ca/residents/education-and-learning/prek-12-education-earlylearning-and-schools/learning-english-as-an-additional-language

Financial assistance: Refugees. (2016, February 26). Retrieved from http:www.cic.gc.ca/english/refugees/outside/resettle-assist.asp

Fleischman, H. L., \& Hopstock, P. J. (1993). Descriptive study of services to limited English proficient students, 1, Executive Summary. Arlington, VA: Development Associates.

Gonzalez, N., Moll, L. C., Tenery, M. F., Rivera, A., Rendon, P., Gonzales, R., \& Amanti, C. (1992). Funds of knowledge for teaching: Using a qualitative approach to connect homes and classrooms. Theory Into Practice, 31(2), 132-141.

Government-assisted refugee resettlement in Canada. (2014, April). Retrieved from http://www.cic.gc.ca/english/pdf/pub/GAR eng.pdf

Harding, S. (1992). Rethinking standpoint epistemology: What is "strong objectivity?" The Centennial Review, 36(3), 437-470.

Huber, J. (2015, November 29). How Canadians can help child refugees arriving in Canada. CBC News. Retrieved from http://www.cbc.ca/news/canada/child-refugees-assistancewelcome-canada-1.3339971

Kanu, Y. (2008). Educational needs and barriers for african refugee students in manitoba. Canadian Journal of Education, 31(4), 915-939.

Kaprielian-Churchill, I., \& Churchill, S. (1994). The pulse of the world: Refugees in our schools.Toronto, ON: OISE Press.

Karabenick, S. A., \& Noda, P. A. C. (2004). Professional development implications of teachers' beliefs and attitudes toward English language learners. Bilingual Research Journal, 28(1), 55-75.

Kumashiro, K. (2004). Against common sense: Teaching and learning towards social justice. New York: NY: Routledge Falmer.

Laroche, J. (2016, April 04). N.S. teachers union says province didn’t prepare for needs of refugee kids. CBC News. Retrieved from http://www.cbc.ca/news/canada/nova$\underline{\text { scotia/teacher-union-refugee-children-education-school-board-1.3520357 }}$

Levels, M., Dronkers, J., \& Kraaykamp, G. (2008). Immigrant children's educational achievement in Western countries: Origin, destination, and community effects on mathematical performance. American Sociological Review, 73(5), 835-853.

Malsbary, C. B. (2015, October 26). Standardized tests are a form of racial profiling [Web log post]. Retrieved from http://www.commondreams.org/views/2015/10/26/standardizedtests-are-form-racial-profiling 
Montgomery, C. (2013). International students and higher education: New perspectives on cultures and communities. Journal of International Students, 3(2), 82-84.

Pinson, H., \& Arnot, M. (2010). Local conceptualizations of the education of asylum-seeking and refugee students: From hostile to holistic models. International Journal of Inclusive Education, 14(3), 247-267.

Raising the bar on Canadian assessment. (2016). Retrieved from http://www.canadiantestcentre.com/CAT4/CAT4-About.php

Regina teachers group calls for more help with Syrian refugees. (2016, March 21). CBC News. Retrieved from http://www.cbc.ca/news/canada/saskatchewan/regina-education-teacherssupport-syrian-refugees-eal-resources-2016-1.3500769

Richards, J. C., \& Farrell, T. S. (2005). Professional development for language teachers: Strategies for teacher learning. New York, NY: Cambridge University Press.

Rolfsen, C. (2016, January 05). Syrian refuges pose challenges for B.C. schools. CBC News. Retrieved from http://www.cbc.ca/news/canada/british-columbia/syrian-refugees-posechallenges-for-b-c-schools-1.3389126

Roxas, K., \& Roy, L. (2012). "That's how we roll": A case study of a recently arrived refugee student in an urban high school. The Urban Review, 44(4), 468-486.

Rutter, J. (2006). Refugee children in the UK. Maidenhead: Open University Press.

Saskatchewan Ministry of Education. (2007). Saskatchewan curriculum mathematics 4. Retrieved from https://www.edonline.sk.ca/bbcswebdav/library/curricula/English/Mathematics/Mathemat ics_4_2007.pdf

Saskatchewan Ministry of Education (2010). Saskatchewan curriculum social studies 5. Retrieved from https://www.edonline.sk.ca/bbcswebdav/library/curricula/English/Social_Studies/Social_ Studies_Education 5 2010.pdf

Saskatchewan Rivers Public School Division. (n.d.). English as an Additional Language (EAL) [Brochure]. Retrieved from https://www.srsd119.ca/departments/teacherinformation/SSS/EAL/EAL\%20handbookv2. pdf

Schools boards want federal funding for Syrian students (2016, April 27). Saskatoon Star Phoenix. Retrieved from http://thestarphoenix.com/news/local-news/school-boards-wantfederal-funding-for-syrian-students

Shapiro, S. (2014). "Words that you said got bigger": English language learners' lived experiences of deficit discourse. Research in the Teaching of English, 48(4), 386-406.

Sirin, S. R., \& Rogers-Sirin, L. (2015). The educational and mental health needs of Syrian refugee children. Washington, DC: Migration Policy Institute. 
Smith, D. E. (1987). The everyday world as problematic: A feminist sociology. Toronto, ON: University of Toronto Press.

Sterzuk, A., \& Vandall, J. (n.d.). Effective practice guidelines: The basics. English as an additional language (EAL) Canada. [Bulletin \#1]. Saskatchewan Ministry of Education. Retrieved from http://publications.gov.sk.ca/documents/11/82984-bulletin-1.pdf

Syria: The story of the conflict (2016, March 11). BBC News. Retrieved from http://www.bbc.com/news/world-middle-east-26116868

Tran, Y. K. (2014). Professional development and teacher efficacy: Contexts of what, when, and wow in serving ELLs. Multicultural Education Studies, 6(2), 81-116.

Tutton, M. (April 4, 2016). Syrian refugee influx straining Halifax-area schools: teachers. CBC News. Retrieved from http://www.cbc.ca/news/canada/nova-scotia/syrian-refugeehalifax-influx-school-education-1.3519427

UN General Assembly. (July 28, 1951). Convention relating to the status of refugees. United Nations, Treaty Series, 189, 137-220. Retrieved from http://www.refworld.org/docid/3be01b964.html

Van Den Bergh, L., Denessen, E., Hornstra, L., Voeten, M., \& Holland, R. W. (2010). The implicit prejudiced attitudes of teachers: Relations to teacher expectations and the ethnic achievement gap. American Educational Research Journal, 47(2), 497-527

Why is EU struggling with migrants and asylum? (2016, March 3). BBC News. Retrieved from http://www.bbc.com/news/world-europe-24583286 